\title{
Harmonization Of Direct Taxation In The Eu And It's Influence On International Taxation
}

\author{
MSc. Matjaž Kovač \\ doctoral candidate for finance and tax law at the Faculty of Law, University of Maribor; \\ a higher education lecturer for the subject Law at Alma Mater Europea; \\ director of LEKSIAKOV, legal, business, financial and tax services 1.t.d. \\ Knafelčeva 30, Maribor, Slovenia, phone +386 30317879
}

\begin{abstract}
The EU's common market is one of the most important aspects of the EU's work. The creation of a common market also includes the elimination of barriers that still prevent the free movement of goods and services. The Member States agreed in the Lisbon Strategy to achieve the goal that Europe should be the most competitive economy in the world by 2020. One of these objectives is also the regulation of the EU tax system. Tax treatment is left to the EU in the EU, and only tax principles are common. The autonomy of Member States in the field of taxes results in 28 different tax systems. The characteristics of corporation taxation in the EU are marked by fiscal competition with many negative impacts on the performance of businesses and on the European economy. Member States are becoming increasingly aware of these negative guidelines and are therefore striving to take steps towards harmonizing direct business taxation on the EU's internal market
\end{abstract}

Keywords: EU common market, tax policy, harmonization of taxes, direct taxation, CCCTB

Tax policy must create such a tax system that will be able to solve the complex social and economic problems that will arise in the coming decades and will have a major impact on the development of labor markets, the development of demand and savings, the development of environmental protection and equitable economic development. The international tax system must be targeted at both developed and underdeveloped countries and developing countries ${ }^{1}$. The OECD should play a major role in this, which should in future develop other countries' inclusion programs in this organization. Tax administration also needs more concrete renovations. New communication services can improve taxation services, which will have positive implications for taxpayers as well as individuals ${ }^{2}$.

\footnotetext{
${ }^{1}$ Pernek F., (2013). Some reflections on tax reforms: experience and caution are the basis for the adoption of successful tax reforms, Money, Tax Review 23, no. 423, pp. 26-29.

${ }^{2}$ Gottsche M., (1997). Wohnsitz - verlagerung naturlicher Personen ins Ausland, Neuwied: Kriftel: Berlin: Luchterhand, pp. 7-11.
} 


\title{
Management, Economics and Accounting
}

\author{
May 03-05 2019, Athens - Greece
}

The EU Commission has proposed some solutions to tackle outstanding issues with regard to the taxation of world income. Thus, under the Directive, a common system of taxes applicable to parent companies and subsidiaries in different Member States is subject to tax by the EU subsidiary under the principle of original parent companies. This made it effective to discourage companies from establishing branches outside the borders or to influence decision-making regarding the location and structure of subsidiaries. Subsidiary profits can only be taxed once, and therefore the directive provides for the neutralization of refunding taxes, in the event that the company chooses to make a new location. Companies in another Member State are absolutely free of taxes on profits. The tax shall be exempt from dividends paid by a company in one Member State to a company in another Member State, provided that that company has at least $25 \%$ of the share capital of the contributors. Such exemption is covered by the tax in the country of origin and the total income tax in the recipient country. In the event of non-deductible costs, Member States may, at their discretion, reduce the tax to $5 \%$ of the dividends received ${ }^{3}$.

A common tax system for mergers and divisions of companies from different Member States is conditional on the merging of national borders, which will no longer affect taxes and companies that are free to connect for economic interest. This Directive defers all taxes on the acquisition of capital until the merger of companies, the abolition of borders and the activities of companies in the direction of aggregation, which will be subsequently regulated.

The basis for bilateral agreements in the field of double taxation is contained in Article 220 of the Treaty of Rome (hereinafter: the Treaty on the EU - TEU), which stipulates that Member States will have to enter into mutual negotiations in order to provide for their citizens the elimination of double taxation in the $\mathrm{EU}^{4}$. In addition to the abolition of double taxation, this article also relates to the methods of taxing world income. Bilateral agreements have a certain right in the content of a Member State to apply the relevant provisions of its tax rules which differ between taxable persons who are not in the same situation in relation to the residence and place of capital investment and the rights of organization compatible with the Treaty of Rome. The situation of the resident and the non-resident is not comparable, since the source of income and income taxation may vary according to the country concerned. The most-privileged regime has shortcomings in that it is unlikely that the parent company will transfer the bulk of revenue to the country of the subsidiary. The principle of maximum benefit could be comparable only with a resident of a third country with whom the country of origin has a tax agreement giving it a favorable position ${ }^{5}$. Tax agreements indirectly affect three areas:

- The effect of the domestic tax regime. Tax rates vary, even where rates of corporate taxes and income taxes are the same, as the tax burden can vary. The timing of commitments, deductions of costs, transfers and delays in covering losses, customs and charges are those elements which make it impossible to make the comparison

\footnotetext{
${ }^{3}$ Lehner M., (1997). EC Law and the Competence to Abolish Double Taxation, Tax Treaties and EC Law, Series on International taxation no. 16, Kluwer Law International, London, pp. $10-13$.

${ }^{4}$ Kostanjevec B., (2013). Conclusion of tax agreements: multilateral agreements as a goal of international harmonization of tax systems, Money, Tax Review 22, no. 425, pp. 34-36.

${ }^{5}$ Kostanjevec B. (2006). International Double Taxation of Enterprises, Company and Work: Journal for Economic, Labor and Social Law, Vol. 32, no. 2, pp. 406-428.
} 


\section{Management, Economics and Accounting}

May 03-05 2019, Athens - Greece

- Tax agreements. Investors from both countries will have access to the groups following agreements that will affect tax rates and time issues

- Recent factors. A general investment climate has an important effect.

The system of taxation of income on an international scale influences investors' decisions regarding the use and transfer of capital at home or abroad. In addition to capital, the factors of the flow and connection of the tax system are also very important factors in the costs of social insurance and the taxation of the income of natural persons. OECD governments have to define the areas of taxation, as this affects the flow of capital and the reduction of interventions, which in turn affects the neutrality of taxation.

\section{HARMONIZATION OF DIRECT TAXATION}

Contrary to indirect taxes, direct taxes (personal income tax, corporate income tax), capital duty are payable on income and capital flows. Direct taxation interferes with the fundamental freedoms, namely the free movement of persons (natural or legal) and the free movement of capital ${ }^{6}$. Free movement of persons includes the right to free stay and business creation, which means that natural persons (workers, self-employed, students, pensioners, etc.) can freely choose their place of residence in the EU. In the common market, not only work and entrepreneurship are subject to the right to free movement, but this also applies to capital. Investors should be able to invest their funds where they consider the risk / yield ratio to be the best. Moreover, the right to establish a seat constitutes a need for the free movement of capital as a cross-border establishment of undertakings which normally involves cross-border movement of capital (assets).

Concerning direct taxation, the EU accepts some sort of agreement that the harmonization of personal income tax should not directly affect these benefits, which still need to be organized at the national level. Co-ordination of corporate taxation is indirectly taken into account in Article 100 of the Treaty of Rome, which provides that the Council of the European Union acting unanimously, on a proposal from the Commission, will legislate on issues relating to the approximation of those provisions of laws, regulations or administrative provisions in the Member States, which directly affect the establishment or functioning of the common market ${ }^{7}$.

Since the establishment of the EU, corporate taxation has received special attention, as this topic is one of the most important elements for the establishment and completion of the internal market. The Neumark report published in 1962 in the area of taxation of legal persons includes several recommendations on the field of corporate taxation. In the Tempell report issued in 1970, a number of

${ }^{6}$ Gondor M., (2011). From Total to structual harmonization on the field of European Direct Taxation, The Annals of The Stefan cel Mare University of Suceava. Fascicle of The Faculty of Economics and Public Administration, Vol. 11 No. 1(13), pp. 269-271.

${ }^{7}$ Auerbach A. J., The Future of Capital Income Taxation, Fiscal Studies 27(4): 399-420. 
initiatives were proposed aimed at achieving a limited degree of harmonization of the taxation system of legal persons, the creation of a tax base and tax rates ${ }^{8}$.

In 1975, the European Commission submitted appropriate proposals for directives recommending a uniform corporate tax rate of corporation tax of between 45 and 55 per cent, a system of partial credit imputations following the example of the French fiscal method with a single tax rate for the shareholder of the company in divided dividends and a $25 \%$ rate of tax on deducting all other dividends other than dividends transferred by subsidiaries to a parent company located in one of the Member States. However, these proposals were not accepted, since the European Economic Community at that time considered that it was necessary to harmonize the rules for setting the tax base before harmonizing tax rates.

The EEC focused more on the system of calculating losses and proposed a directive on the transfer of losses to future tax periods. The European Commission has proposed to harmonize the legislation for the transmission of the loss backwards for three years and the unlimited transfer of the loss to the next tax periods. Unfortunately, Proposal was unfortunately subsequently withdrawn. In 1988, the European Commission prepared a proposal to harmonize the tax base of companies, which, due to unwillingness to accept the majority of Member States, has never been established. In 1990, the European Commission temporarily suspended the broad objective of harmonizing corporation tax and instead focused on eliminating the remaining forms of double taxation. It made recommendations in three main areas, namely; the elimination of tax obstacles to cross-border investments and intraCommunity shares, the establishment of a minimum legal tax rate of corporation tax of $30 \%$ and the preparation of common rules for calculating the tax base in order to avoid excessive tax competition. Among the three aforementioned objectives, some progress was made only for the first objective ${ }^{9}$.

The EU Treaty does not contain specific legislative powers in the field of direct taxation. The legislation on business taxation is based on Article 115 of the Treaty on European Union ${ }^{10}$ (hereinafter TFEU), which forms the basis for a Directive approximating those laws, regulations and administrative provisions of the Member States which directly affect the establishment or functioning of the internal market and provides for the consensus and consultation procedure. Article 65 TFEU relates to the free movement of capital and allows Member States to deal differently with taxable persons who are not in the same situation with regard to their place of residence or the place where their capital is invested. Articles 110-113 TFEU require Member States to open negotiations on the elimination of double taxation in the Community and Article 55 prohibits discrimination on grounds of equity participation in undertakings. However, most of the direct taxation regulations do not fall within the scope of EU legislation.

In the 1990 Taxation Guidelines (SEC (90) 601), the European Commission gave priority to the three previously announced proposals, which were subsequently adopted, namely the Merger Directives

${ }^{8}$ Deveraux M.P., Griffith R, Klemm A., (2002). Corporate Income Tax Reforms and International Tax Competition, Economic Policy, 35, pp. 451-495.

${ }^{9}$ Kind H.J., Midelfart K.H., Schjelderup G., Corporate Tax System, Multinational Enterprises and Economic Integration, Journal of International Economics, Elsevier 65(2), pp. 507-521.

${ }^{10}$ See also: https://www.ecb.europa.eu/ecb/legal/1341/1342/html/index.sl.html 


\section{Management, Economics and Accounting}

May 03-05 2019, Athens - Greece

(90/434 / EEC), which deal with capital gains in (90/435 / EEC), which eliminates the double taxation of dividends paid by a subsidiary in one Member State to a parent company in another Member State and to the Arbitration Convention (90/435 / EEC), which introduces a procedure for settling disputes concerning the profits of related companies. The characteristics of sharp debates between Member States are reflected in the proposed Directives on the payment of interest and royalties paid by parent companies and subsidiaries in 1991. Although the proposal was amended two years later and endorsed by the European Parliament, the Commission subsequently withdrew it since the Council could not agree on it. In 1998, a new version of the proposal, which was adopted as Directive 2003/49 / EC, was presented as part of the Monti package.

In 1991, the Ruding Committee of Independent Experts was established, which proposed in its report a work program to eliminate double taxation, harmonize tax rates for businesses, and ensure full transparency of the various Member States' tax reliefs in order to encourage investment. The Commission then proposed amendments to Merger Directives or parent companies and subsidiaries (COM (93) 293) and drew attention to the two long-standing proposals for directives, namely the transfer of loss (COM (84) 404) and the losses of business units and subsidiaries in other Member States (COM (90) 595).

In 1996, the Commission presented a new approach to taxation. In corporate taxation, the corporate governance code of corporate taxation was adopted as a resolution of the Council in 1998. Its report was presented by the European Commission in 1999, setting out 66 tax procedures, which should be abolished within five years.

In 1998, Member States asked the Commission to draw up an analytical study on the taxation of corporate income in the European Community. A study, prepared by two expert groups (SEC (2001) 1681), was published in 2001. In a communication (COM (2001) 582), the Commission found that the main difficulty of businesses stems from the need for internal market to face different national rules. The Commission has proposed a number of different approaches to provide companies with a common basis for their activities in the EU: taxation in the home country, an optional common consolidated tax base, a European company tax, or a mandatory and fully harmonized tax base. The proposals were addressed at the 2002 conference. In 2004, a working group was set up and its results were published in the Commission's proposal for a Commission directive (COM (2011) 121). The proposed "common consolidated corporate tax base" (CCCTB) would mean that companies would have, inter alia, a single tax administration system where they could apply for a refund. It could also consolidate all gains and losses from operating in the EU. Member States would retain the competence to determine corporation tax entirely.

\subsection{Harmonization of taxation on mergers, divisions, transfers of assets and the exchange of shares in companies of different Member States}

In the Member States of the European Union, tax neutrality in status changes is required in a separate directive or directive, which provides that the tax system and tax policy must play an undisputed role in the process of company transformation. This area is dealt with in detail in Directive 90/434 / EEC (with amendments) on the common system of taxation applicable to mergers, divisions, transfers of assets and exchange of shares of companies from different Member States. The fundamental premise 
of the directive is that mergers, divisions, transfers of assets and exchanges of shares in capital companies must not give rise to taxation. The directive facilitates reorganisations (mergers, divisions, transfers of assets, swapping of equity holdings) by postponing taxation under certain conditions (for example, capital gains on an asset are not taken into account in the merger or division, but only at a later sale). A more favorable tax regime may also be imposed by other companies (not only equity securities whose capital is securities), such as a limited liability company. The EU's solution to this directive was to not be taxed on capital gains when the merger or payment of assets occurs, but on the accumulation of this profit ${ }^{11}$. This solution is interesting for the creation of "European companies", as many companies usually merged with the merger of companies originally established in different Member States ${ }^{12}$.

In 2005, the directive was amended ${ }^{13}$. The validity of this Directive has also extended to the field of the transfer of the registered office of a European company (SE) and the European Cooperative Society (SCE) from one Member State to another and also provides for the exemption of capital gains taxation in the event that the acquiring company owns shares in a transferring company .

\subsection{Harmonization of the taxation system of parent companies and subsidiaries}

Council Directive 90/435 / EEC of 23 July 1990 on the common system of taxation applicable in the case of parent companies and subsidiaries of different Member States has been substantially amended several times ${ }^{14}$. In order to create conditions similar to those in the internal market in the Community

${ }^{11}$ In Hans Markus Kofoed vs Skatteministeriet (C 321/05) the Court of Justice ruled that the profits paid by the acquiring company shortly after the exchange of shares were paid to the shareholders of the acquired company, but not a substantial part of the counterparty that the acquiring company must pay may therefore be included in the calculation of the 'cash payment' provided for in Article 2 of the Directive, since this means a "replacement of capital shares." Consequently, Article 8 of this Directive opposes in principle the taxation of such a swap of shares unless the rules of national law on the abuse of rights, tax evasion or avoidance of taxation in accordance with Article 11 of that directive, thereby justifying its taxation. Hans Markus Kofoed vs Skatteministeriet (C 321/05).

${ }^{12}$ In this regard, the term 'cash payment' to the shareholders of the acquired company in the context of the exchange of shares in the meaning of Article 2 of this Directive relates to cash benefits which are in the nature of genuine consideration for the acquisition operation, namely services which have been binding on them as an additive to the allocation of securities representing the capital of the acquiring company. In each case, in all circumstances, it is necessary to verify that the charge in question has the character of a binding consideration for the acquisition operation.

${ }^{13}$ Council Directive 2005/19 / EC of 17 February 2005 amending Directive 90/434 / EEC on the common system of taxation applicable to mergers, divisions, transfers of assets and exchanges of shares concerning companies of different Member States.

${ }^{14}$ Council Directive of 23 July 1990 on the common system of taxation applicable in the case of parent companies and subsidiaries of different Member States (90/435 / EEC). 


\section{Management, Economics and Accounting}

May 03-05 2019, Athens - Greece

in order to ensure the efficient functioning of such an internal market, it is necessary to integrate into groups of companies from different Member States. These operations must not be impeded by restrictions, shortcomings or distortions arising in particular from Member States' tax regulations. Therefore, for such groupings of companies from different Member States, tax rules should be set up which are neutral from the point of view of competition and enable companies to adapt to the requirements of the internal market in order to increase productivity and improve their competitive power at the international level. The result of such grouping is the formation of groups of parent companies and subsidiaries ${ }^{15}$.

Prior to the entry into force of Directive 90/435 / EEC, the existing tax rules governing the relationships between parent companies and subsidiaries differed in different Member States and were generally less favorable than those applicable to parent companies and subsidiaries in the same Member State. Therefore, cooperation between companies from different Member States was in a less favorable situation compared to the participation of companies from the same Member State. This less favorable situation had to be resolved by the introduction of a common system at Community level in order to facilitate the integration of companies into groups.

Where a parent company receives a distributed profits from a connection with its subsidiary, the parent company's state must either refrain from taxing that profits or tax that profit and at the same time allow the parent company to deduct a portion of the corporate tax relating to that profit and paid by the subsidiary. In order to ensure fiscal neutrality, the profits distributed by the subsidiary to its parent company should be exempt from withholding tax.

The payment from the distribution of profit and the receipt of this payment by the permanent establishment of the parent company must result in the same treatment as is used between the subsidiary and the parent company. This includes situations where the parent company and the subsidiary are located in the same Member State and the permanent establishment in another Member State. On the other hand, it seems that the Member State concerned may consider situations where a permanent establishment and a subsidiary are located in the same Member State, without prejudice to the application of the principles of the contract under national law.

${ }^{15}$ In the context of the EU, the Commission places great emphasis on simplifying and clarifying European law in order to make it more clear and accessible to the ordinary citizen, giving it new opportunities and the possibility of using the special rights conferred on it by this law. This goal can not be achieved until many of the rules, which have been repeatedly amended, are often very essential, remain scattered so that they have to be searched partially in the original act and partly in later acts that change it. In order to establish the existing rules, considerable research work is required by comparing a number of different acts. On 8 October 2001, the Council adopted Regulation (EC) No. 2157/2001 on the Statute for a European Company (SE) and Directive 2001/86 / EC supplementing the Statute for a European company with regard to the involvement of employees. On 22 July 2003, the Council adopted Regulation (EC) No. 1435/2003 on the Statute for a European Cooperative Society (SCE) and Directive 2003/72 / EC supplementing the Statute for a European Cooperative Society with regard to the involvement of employees. 


\section{Management, Economics and Accounting}

May 03-05 2019, Athens - Greece

Given the treatment of permanent establishments, Member States should lay down conditions and legal instruments to protect national tax revenues and avoid circumvention of national legislation in accordance with the principles of the TEU and taking into account internationally accepted tax regulations. Where groups are organized in the form of chains and the distribution of profits to the parent company takes place through a chain of branches, double taxation with the exception of a credit on tax already paid is eliminated. In the case of a tax credit on tax already paid, the parent company must be able to deduct any tax paid by any subsidiary in the chain, provided that the conditions of the Directive are met.

\subsection{Harmonization of the system of taxation of interest and royalty payments of affiliated companies}

Council Directive 2003/49 / EC on the common system of taxation applicable to interest and royalty payments made between associated companies of different Member States has proved effective within the limits of its scope. In a single market that has the characteristics of the internal market, transactions between companies from different Member States must not be taxed less favorably than deals with companies in the same Member State ${ }^{16}$.

National tax regulations, together with bilateral and multilateral agreements, where they exist, can not always ensure the elimination of double taxation, and their use often results in burdensome administrative formalities and problems with the availability of the funds of these companies. It is necessary to ensure that payments of interest and royalties in a Member State are taxed only once. Elimination of the taxation of payments of interest and royalties in the Member State in which they are incurred, irrespective of whether the tax is collected by deduction at source or by assessment, is the most appropriate way to eliminate those formalities and problems and to ensure equitable tax treatment of national and cross-border transactions ; in particular, such taxes must be abolished in respect of such payments made between affiliated companies from different Member States and between permanent establishments of such companies. The regime is intended to apply only to the amounts of any interest or royalty payments agreed between the payer and the beneficial owner if there is no special relationship between them. It is also necessary that Member States do not prevent the adoption of appropriate measures to prevent fraud or abuse.

\subsection{Harmonization of the tax base of corporate income tax}

Companies wishing to cross-border across the EU face high barriers and distortions of the market due to 28 different corporate tax systems. Tax obstacles to cross-border business are particularly large for small and medium-sized enterprises, which usually do not have the means to eliminate market

\footnotetext{
${ }^{16}$ However, it follows from the first report on the application of Directive 2003/48 / EC that the Directive does not fully meet the objectives set out in the ECOFIN Consensus Conclusions of 26 and 27 November 2000. In particular, it does not cover certain financial instruments equivalent to interest-bearing securities, and some indirect methods of ownership of interest-bearing securities.
} 


\section{Management, Economics and Accounting}

May 03-05 2019, Athens - Greece

inefficiencies. The network of conventions on the avoidance of double taxation between Member States does not provide a suitable solution. The current Union legislation on taxation of legal persons deals with only a small number of specific problems.

A system that would allow companies to treat EU corporations as a single market in relation to EU corporate income tax would facilitate the cross-border activity of resident companies in the EU and promote the objective of making the EU more competitive for international investment. Such a system could best be achieved by allowing groups of taxable companies in more than one Member State to regulate their tax matters in the EU on the basis of a single set of rules for calculating the tax base and cooperating with one tax administration. These rules should also be available to entities that are liable to pay corporate income tax in the EU and are not part of the group. Thus, under the aegis of the Commission of the EU and its working bodies, the idea of creating a system of a common consolidated corporate tax base (hereinafter CCCTB) was formed ${ }^{17}$.

The CCCTB is used to tackle some of the major tax barriers that restrict growth in the single market. In the absence of common tax regulations, the interaction of national tax systems often leads to excessive taxation and the occurrence of double taxation. Companies are faced with major administrative and coordination costs. Such a situation creates barriers to investment in the EU and results in non-compliance with the priorities set out in the Europe 2020 Strategy - A strategy for smart, sustainable and inclusive growth ${ }^{18}$. The CCCTB is an important initiative which contributes to eliminating the barriers to the completion of the single market ${ }^{19}$, identifying in the Annual Growth Survey as an incentive to stimulate growth from the outset to accelerate the growth and creation of new jobs ${ }^{20}$.

The proposed system of corporate taxation would be technically in three stages. All taxable profits and losses of each group of companies would be consolidated, irrespective of the location of individual companies in the group. The established tax base of a group of companies would be attributed to the individual group companies using the distribution formula. The tax base attributed to an individual group company would be taxed at the national tax rate of the country in which the company is located. When determining the tax rate for the established share of the profits of an undertaking located in its territory, Member States would remain independent.

A common approach would ensure the coherence of national tax systems on the basis of a common tax base, but would not interfere with the rights of countries to form a tax rate. Each Member State will apply its own tax rates to its share of the taxable person's tax base. Differences in the determination of

\footnotetext{
${ }^{17}$ Aujean M., (2008). The CCCTB Project and the Future of European Taxation in Lang M. et.al., Common Consolidate Corporate Tax Base, Linde Verlag, Vienna, pp 11-37.

${ }^{18}$ Communication from the Commission EUROPE 2020 - A strategy for smart, sustainable and inclusive growth, COM (2010) 2020 of 3 March 2010.

19 Communication from the Commission Towards a Single Market Act - For a highly competitive social market economy - 50 proposals for improving work, business and exchanges, COM (2010) 608 of 27 October 2010.

${ }^{20}$ Communication from the Commission Annual Growth Survey: Promoting EU Action to Achieve a Global Response to the Crisis, COM (2011) 11 of 12 January 2010.
} 


\section{Management, Economics and Accounting}

May 03-05 2019, Athens - Greece

the tax rates of individual Member States provide for a degree of tax competition which is supposed to be maintained on the internal market. It allows Member States to take into account both their competitiveness in the EU internal market and the regulation and balancing of the budgetary needs of each Member State in tax planning ${ }^{21}$.

With the introduction of the CCCTB, problems arising from jurisdiction contracts and the taxation of revenues generated by European companies outside the EU or outside the CCCTB area could arise. If a practice of separate profits would remain in use in relation to non-EU countries, this would probably lead to the parallel use of different systems. This would entail an administrative burden for businesses, which would reduce the benefits of taxation through the CCCTB. The question arises, to what extent high capital mobility, globally, diminishes the benefits of fiscal coordination within the EU ${ }^{22}$.

A more important advantage of the CCCTB is the ability to identify profits and losses at the level of an international company, which would enable the loss of businesses at EU level to be covered. Profits and losses of a group of companies should not be distinguished by countries in which individual subsidiaries of the group are located, but from the outset all taxable profits and losses, irrespective of the location of individual companies in the group, would be consolidated. Thus, the spillover of profits between the companies of the group would lose sense, as the introduction of such a system would also eliminate the need to determine the transfer prices for transactions between individual companies of the CCCTB system ${ }^{23}$.

The taxpayer's income must be taxable, unless explicitly exempted. The CCCTB system exempts income in the form of dividends, proceeds from the disposal of shares of a company that is not part of the group and the profit of permanent establishments abroad. In granting double taxation, most Member States exempt dividends and proceeds from the alienation of shares, in order to avoid the calculation of the deduction of tax paid abroad, to which taxpayers are entitled, in particular where such a justification must be taken into consideration the corporation tax levied by the taxable person the company is paid by the dividend payer. It is also necessary to simplify the exemption of income from the rest of the world. Taxable income should be reduced by operating expenses and some other items. Deductible operating expenses should normally include all the costs associated with the sale and expenses associated with the creation, maintenance and insurance of income. R \& D costs and costs arising from the collection of equity or debt for business purposes should be deducted. A list of non-deductible expenditure should also be prepared ${ }^{24}$. Tangible and intangible long-term assets should be depreciated separately, while remaining required to be included in the group of assets. Depreciation

\footnotetext{
${ }^{21}$ Aujean M., (2008), pp. 11-37.

22 Martini Jimenez A. in Calderon Carrero J. M., (2008) Administrative Cooperation Exchange of Information in the Context of the CCCTB in Lang M. et.al., Common Consolidate Corporate Tax Base, Linde Verlag, Vienna, pp. 93-112.

23 Tenore M., (2008) Requirements to Consolidate and Changes in the Level of Ownership in Lang M. et.al., Common Consolidate Corporate Tax Base, Linde Verlag, Vienna, pp. 63-93.

${ }^{24}$ Navarro A. in Soter Roch M. T., (2008). Mesaurment of Income and Expenses in Lang M. et.al., Common Consolidate Corporate Tax Base, Linde Verlag, Vienna, pp. 421-441.
} 


\section{Management, Economics and Accounting}

May 03-05 2019, Athens - Greece

in the group means simplification for tax authorities and taxpayers, since it eliminates the need to prepare and maintain the list for each type of fixed asset and its useful life ${ }^{25}$.

When transferring the loss, taxpayers are allowed to transfer the loss to a future period for an indefinite period of time, and the transfer of loss to the previous period may not be allowed. Since the loss is transferred in the future to the taxpayer to pay tax on his real income, there is no reason to limit the deadline for the transfer to the future period. The transfer of losses to the previous period is relatively rare in the practice of the Member States and entails the excessive complexity of the procedures ${ }^{26}$.

Consolidation is an essential element of the CCCTB, as the main tax barriers faced by companies in the EU can only be addressed in this context. Consolidation eliminates formalities relating to transfer pricing and double taxation within the groups. In addition, the loss incurred by taxpayers is automatically offset by the profits generated by other members of the same group. Consolidation must include rules for the distribution of the result among the Member States in which the members of the group own their business units ${ }^{27}$.

The distribution formula of the consolidated tax base contains three equally weighted factors (work, assets and sales). The labor factor is calculated on the basis of remuneration for work and number of employees (each item represents half). The asset factor consists of all tangible fixed assets. Intangible and financial assets should be excluded from the formula because of their mobile nature and the risks of avoiding the system. Finally, sales must be taken into account in order to ensure the fair participation of the Member State of destination. These factors and weightings must ensure that profits are taxed where they are earned. As an exception to the general principle, where the result of a distribution does not represent a fair amount of business activity, a substitution method is defined with a safeguard clause ${ }^{28}$.

\section{CONCLUSION}

The system of taxation of income on an international scale influences investors' decisions regarding the use and transfer of capital at home or abroad. In addition to capital, the factors of the flow and connection of the tax system are also very important factors in the costs of social insurance and the taxation of the income of natural persons. OECD governments have to define the areas of taxation, as

${ }^{25}$ Litwinczuk H. in Supera - Markowska M., (2008). Depreciation Rules in CCCTB in Lang M. et.al., Common Consolidate Corporate Tax Base, Linde Verlag, Vienna, pp. 305-323.

${ }^{26}$ Moreno Gonzales G. in Sanz Diaz-Palacios J. A., (2008). The CCCTB: Treatment of Losses in Lang M. et.al., Common Consolidate Corporate Tax Base, Linde Verlag, Vienna, pp. 441460 .

${ }^{27}$ Oestreicher A., (2008). CCCTB - Methods of Consolidation in Lang M. et.al., Common Consolidate Corporate Tax Base, Linde Verlag, Vienna, pp. 517-547.

${ }^{28}$ European Comission, CCCTB; Possible elements of the sharing mechanism, Brussels, 13 November 2007. 


\section{Management, Economics and Accounting}

May 03-05 2019, Athens - Greece

this affects the flow of capital and the reduction of interventions, which in turn affects the neutrality of taxation.

The CCCTB system should provide more favorable conditions for investment in the single market, while reducing management costs. Enterprises would gain competitive advantages in the internal market, mainly due to the elimination of transfer (transfer) prices, the transfer of losses through national systems in the group as well as the reorganization of the duty-free system. The positive effects of the introduction of the CCСТВ model, on the other hand, outweigh the introduction of certain additional financial and administrative costs that should be taken into account by the national tax authorities in case of system implementation at first instance. The introduction of the CCCTB would increase the transparency of taxation across EU Member States, thereby helping to reduce fiscal uncertainty, as international companies could reasonably calculate in advance how much the real tax burden would be at the level of the whole company. This system would discourage companies from certain types of behavior for purely fiscal reasons, which would reduce the distortion of investment decisions and increase economic efficiency or optimize the allocation of resources.

\section{REFERENCES}

[1] Amparo Grau Ruiz M., (2008). Administrative Cooperation - Excange of Information in the Context of the CCCTB in Lang M. et.al., Common Consolidate Corporate Tax Base, Linde Verlag, Vienna, pp. 945-957.

[2] Auerbach A. J., The Future of Capital Income Taxation, Fiscal Studies 27(4), pp 399-420.

[3] Aujean M., (2008). The CCCTB Project and the Future of European Taxation in Lang M. et.al., Common Consolidate Corporate Tax Base, Linde Verlag, Vienna, pp 11-37.

[4] Council Directive 2005/19 / EC of 17 February 2005 amending Directive 90/434 / EEC on the common system of taxation applicable to mergers, divisions, transfers of assets and exchanges of shares concerning companies of different Member States.

[5] Council Directive of 23 July 1990 on the common system of taxation applicable in the case of parent companies and subsidiaries of different Member States (90/435 / EEC).

[6] Communication from the Commission Annual Growth Survey: Promoting EU Action to Achieve a Global Response to the Crisis, COM (2011) 11 of 12 January 2010.

[7] Communication from the Commission EUROPE 2020 - A strategy for smart, sustainable and inclusive growth, COM (2010) 2020 of 3 March 2010.

[8] Communication from the Commission Towards a Single Market Act - For a highly competitive social market economy - 50 proposals for improving work, business and exchanges, COM (2010) 608 of 27 October 2010.

[9] Deveraux M.P., Griffith R, Klemm A., (2002). Corporate Income Tax Reforms and International Tax Competition, Economic Policy, 35, pp 451-495.

[10] European Comission, CCCTB; Possible elements of the sharing mechanism, Brussels, 13 November 2007.

[11] Gondor M., (2011). From Total to structual harmonization on the field of European Direct Taxation, The Annals of The Stefan cel Mare University of Suceava. Fascicle of The Faculty of Economics and Public Administration, Vol. 11 No. 1(13), pp 269-271.

[12] Gottsche M., (1997). Wohnsitz - verlagerung naturlicher Personen ins Ausland, Neuwied: Kriftel: Berlin: Luchterhand, pp 7-11. 


\section{Management, Economics and Accounting}

May 03-05 2019, Athens - Greece

[13] Kind H.J., Midelfart K.H., Schjelderup G., Corporate Tax System, Multinational Enterprises and Economic Integration, Journal of International Economics, Elsevier 65(2), pp 507-521.

[14] Kostanjevec B., (2006). International Double Taxation of Enterprises, Company and Work: Journal for Economic, Labor and Social Law, Vol. 32, no. 2, pp 406-428.

[15] Kostanjevec B., (2013). Conclusion of tax agreements: multilateral agreements as a goal of international harmonization of tax systems, Money, Tax Review 22, no. 425, pp 34-36.

[16] Lehner M., (1997). EC Law and the Competence to Abolish Double Taxation, Tax Treaties and EC Law, Series on International taxation no. 16, Kluwer Law International, London, pp 10-13.

[17] Litwinczuk H. in Supera - Markowska M., (2008). Depreciation Rules in CCCTB in Lang M. et.al., Common Consolidate Corporate Tax Base, Linde Verlag, Vienna, pp. 305-323.

[18] Martini Jimenez A. in Calderon Carrero J. M., (2008). Administrative Cooperation Exchange of Information in the Context of the CCСТВ in Lang M. et.al., Common Consolidate Corporate Tax Base, Linde Verlag, Vienna, pp. 93-112.

[19] Moreno Gonzales G. in Sanz Diaz-Palacios J. A., (2008). The CCCTB: Treatment of Losses in Lang M. et.al., Common Consolidate Corporate Tax Base, Linde Verlag, Vienna, pp. 441-460.

[20] Navarro A. in Soter Roch M. T., (2008). Mesaurment of Income and Expenses in Lang M. et.al., Common Consolidate Corporate Tax Base, Linde Verlag, Vienna, pp. 421-441.

[21] Neale T., (2008). CCCTB: How fare we got and what are the next steps? in Lang M. et.al., Common Consolidate Corporate Tax Base, Linde Verlag, Vienna, pp. 63-93.

[22] Oestreicher A., (2008). CCCTB - Methods of Consolidation in Lang M. et.al., Common Consolidate Corporate Tax Base, Linde Verlag, Vienna, pp. 517-547.

[23] Pernek F., (2013). Some reflections on tax reforms: experience and caution are the basis for the adoption of successful tax reforms, Money, Tax Review 23, no. 423, pp. 26-29.

[24] Tenore M., (2008). Requirements to Consolidate and Changes in the Level of Ownership in Lang M. et.al., Common Consolidate Corporate Tax Base, Linde Verlag, Vienna, pp. 6393. 